\title{
Cohnella luojiensis sp. nov., isolated from soil of a Euphrates poplar forest
}

\author{
Feng Cai, ${ }^{1}$ Yang Wang, ${ }^{1}$ Huan Oi, ${ }^{1}$ Jun Dai, ${ }^{1}$ Bo Yu, ${ }^{1}$ Hongli An, ${ }^{1}$ \\ Erkin Rahman ${ }^{2}$ and Chengxiang Fang ${ }^{1}$ \\ ${ }^{1}$ China Center for Type Culture Collection (CCTCC), College of Life Sciences, Wuhan University, \\ Wuhan 430072, PR China \\ ${ }^{2}$ College of Life Science and Technology, Xinjiang University, Urumchi 830046, PR China
}

Correspondence

Chengxiang Fang

cxfang@whu.edu.cn

\begin{abstract}
A novel strain, $\mathrm{HY}-22 \mathrm{R}^{\top}$, was isolated from soil of a Euphrates poplar forest in Xinjiang, China. The cells were Gram-positive-staining, rod-shaped and motile by means of peritrichous flagella.

Growth occurred at $10-37{ }^{\circ} \mathrm{C}$ (optimum $30{ }^{\circ} \mathrm{C}$ ), at $\mathrm{pH} 7.0-8.0$ (optimum pH 7.0) and with 0$1 \% \mathrm{NaCl}$. A phylogenetic analysis based on $16 \mathrm{~S}$ rRNA gene sequences revealed that strain $\mathrm{HY}-$ $22 \mathrm{R}^{\top}$ was closely related to Cohnella phaseoli GSPC1 ${ }^{\top}$ ( $96.3 \%$ sequence similarity). The major respiratory quinone was $M K-7$ and the predominant fatty acids were anteiso- $C_{15: 0}$, iso- $C_{15: 0}$, iso- $\mathrm{C}_{16: 0}$ and $\mathrm{C}_{16: 0}$. The major polar lipids were diphosphatidylglycerol, phosphatidylglycerol and phosphatidylethanolamine. The DNA G+C content was $49.6 \mathrm{~mol} \%$. On the basis of the phylogenetic, physiological and chemotaxonomic data, strain $\mathrm{HY}-22 \mathrm{R}^{\top}$ represents a novel species in the genus Cohnella, for which the name Cohnella luojiensis sp. nov. is proposed. The type strain is $\mathrm{HY}-22 \mathrm{R}^{\top}$ (=CCTCC AB $208254^{\top}=$ NRRL B-59213 ${ }^{\top}$ ).
\end{abstract}

The genus Cohnella, a member of the family Paenibacillaceae, was proposed by Kämpfer et al. (2006) and its description was emended by García-Fraile et al. (2008). At the time of writing, it comprises six species, Cohnella thermotolerans (Kämpfer et al., 2006), C. hongkongensis (Kämpfer et al., 2006), C. laeviribosi (Cho et al., 2007), C. phaseoli (GarcíaFraile et al., 2008), C. yongneupensis and C. ginsengisoli (Kim et al., 2010). Members of the genus Cohnella are sporeforming, aerobic and rod-shaped and contain $\mathrm{MK}-7$ as the main menaquinone and iso- $\mathrm{C}_{16: 0}$, anteiso- $\mathrm{C}_{15: 0}$ and $\mathrm{C}_{16: 0}$ as major fatty acids. In this study, a novel member of the genus Cohnella is characterized.

Strain HY- $22 \mathrm{R}^{\mathrm{T}}$ was isolated from a soil sample of a Euphrates poplar forest in Xinjiang, China. The soil sample was diluted with sterile water and the dilutions were plated onto half-strength R2A (Difco) plates. The strain was isolated after incubation for 2 days at $30{ }^{\circ} \mathrm{C}$.

Growth on various standard bacteriological media was tested, using nutrient agar (NA), tryptic soy agar (TSA), R2A and marine agar (MA) (all from Difco). For the experiments described below, TSA was used as the basal medium. Gram-staining was carried out using the procedure described by Doetsch (1981). The flagellation type was determined by electron microscopy after incubation for $48 \mathrm{~h}$. Endospores were stained according to the Schaeffer-Fulton method (Smibert \& Krieg, 1994). Cell

The GenBank/EMBL/DDBJ accession number for the 16S rRNA gene sequence of strain $\mathrm{HY}-22 \mathrm{R}^{\top}$ is GQ214052. motility was observed using phase-contrast microscopy (Olympus BX51) and the hanging-drop technique with cells grown for 2 days at $30{ }^{\circ} \mathrm{C}$. Growth at $4,10,15,20,28$, $30,37,42$ and $45{ }^{\circ} \mathrm{C}$ and at pH 5.0-10.0, in increments of $0.5 \mathrm{pH}$ units, was assessed on TSA. Oxidase activity was evaluated via the oxidation of $1 \% p$-aminodimethylaniline oxalate and catalase activity was determined by bubble production with $3 \%(\mathrm{v} / \mathrm{v})$ hydrogen peroxide solution. Tolerance of $\mathrm{NaCl}(0-6 \%, w / v$, in increments of $1 \%)$ was determined. Further biochemical characteristics were determined using the API 20NE, API ID 32GN and API ZYM systems (bioMérieux), according to the manufacturer's instructions.

Cells of strain HY-22R $\mathrm{R}^{\mathrm{T}}$ were Gram-positive-staining, rodshaped $(0.4-0.6 \times 1.2-3.5 \mu \mathrm{m})$ and motile by means of peritrichous flagella. Subterminal oval spores appeared within the cells after growth for 7 days. Strain $H Y-22 R^{T}$ grew aerobically at $10-37{ }^{\circ} \mathrm{C}$, with an optimum of $30{ }^{\circ} \mathrm{C}$, at $\mathrm{pH}$ 6.0-8.0, with an optimum of $\mathrm{pH} 7.0$, and with $0-1 \%$ $(\mathrm{w} / \mathrm{v}) \mathrm{NaCl}$. The results for oxidase and catalase tests were positive. Colonies were opaque, white, convex and about $1 \mathrm{~mm}$ in diameter after growth at $30{ }^{\circ} \mathrm{C}$ for $48 \mathrm{~h}$. The strain grew well on TSA, R2A and MA, but did not grow on NA. The phenotypic properties that differentiate strain $\mathrm{HY}-22 \mathrm{R}^{\mathrm{T}}$ from related strains are listed in Table 1 and the species description.

To measure the $\mathrm{G}+\mathrm{C}$ content of the chromosomal DNA, genomic DNA from the novel strain was extracted and purified as described by Moore \& Dowhan (1995) and 
Table 1. Differential phenotypic characteristics of strain HY$22 \mathrm{R}^{\top}$ and the type strains of phylogenetically closely related Cohnella species

Strains: 1, Cohnella luojiensis sp. nov. HY-22R ${ }^{\mathrm{T}} ; 2$, C. phaseoli KACC $13436^{\mathrm{T}}$; 3, C. hongkongensis KACC $11644^{\mathrm{T}}$; 4, C. thermotolerans KACC $11643^{\mathrm{T}}$. All data are from this study. + , Positive; $(+)$, weakly positive; - , negative.

\begin{tabular}{|c|c|c|c|c|}
\hline Characteristic & 1 & 2 & 3 & 4 \\
\hline \multicolumn{5}{|l|}{ Growth at/with: } \\
\hline $42{ }^{\circ} \mathrm{C}$ & - & + & + & + \\
\hline $2 \% \mathrm{NaCl}$ & - & + & + & - \\
\hline Nitrate reduction & - & + & + & - \\
\hline \multicolumn{5}{|l|}{ Enzyme activity (API ZYM) } \\
\hline$N$-Acetyl- $\beta$-glucosaminidase & - & $(+)$ & - & - \\
\hline Acid phosphatase & - & $(+)$ & + & + \\
\hline Alkaline phosphatase & - & - & + & $(+)$ \\
\hline Cystine arylamidase & - & - & - & $(+)$ \\
\hline Valine arylamidase & - & - & $(+)$ & $(+)$ \\
\hline$\alpha$-Fucosidase & - & $(+)$ & + & - \\
\hline$\alpha$-Galactosidase & + & + & - & + \\
\hline$\alpha$-Glucosidase & - & + & + & + \\
\hline$\beta$-Glucosidase & - & + & + & + \\
\hline \multicolumn{5}{|c|}{ Assimilation (API 20NE, API 32GN) of: } \\
\hline $\mathrm{N}$-Acetylglucosamine & - & + & - & - \\
\hline L-Arabinose & + & + & - & + \\
\hline L-Fucose & + & + & + & - \\
\hline Glycogen & - & + & - & + \\
\hline Inositol & + & - & - & - \\
\hline D-Mannitol & + & - & + & + \\
\hline L-Rhamnose & - & + & + & + \\
\hline D-Sorbitol & - & - & + & + \\
\hline Potassium gluconate & - & - & + & - \\
\hline Potassium 2-ketogluconate & - & + & - & + \\
\hline
\end{tabular}

degraded enzymically into nucleosides and the $\mathrm{G}+\mathrm{C}$ content was then determined as described by Mesbah et al. (1989) using reversed-phase HPLC (UltiMate 3000; Dionex). Respiratory quinones were isolated from lyophilized cells as described by Collins et al. (1977) and were analysed by HPLC as described by Xie \& Yokota (2003). For cellular fatty acid analysis, strain $\mathrm{HY}-22 \mathrm{R}^{\mathrm{T}}$ and strains of phylogenetically closely related Cohnella species were cultivated on TSA medium at $30{ }^{\circ} \mathrm{C}$ for 2 days before harvesting the cell biomass. The fatty acid methyl esters were determined according to the protocol of the Sherlock Microbial Identification System (MIDI) and GC (model 6890; Agilent) using the Microbial Identification software package (Sasser, 1990). Polar lipids were extracted and analysed by the methods of Tindall (1990) by using twodimensional TLC (silica gel $60 \mathrm{~F}_{254}$ plates, layer thickness $0.2 \mathrm{~mm}$, no. 5554; Merck).

The DNA $\mathrm{G}+\mathrm{C}$ content of strain $\mathrm{HY}-22 \mathrm{R}^{\mathrm{T}}$ was $49.6 \mathrm{~mol} \%$. Strain $\mathrm{HY}-22 \mathrm{R}^{\mathrm{T}}$ contained menaquinone 7 (MK-7) as the predominant isoprenoid quinone (99.7\%); in addition, a small amount $(0.3 \%)$ of MK-6 was detected.
These characteristics were in agreement with those of members of the genus Cohnella. The fatty acid pattern of strain HY-22 $\mathrm{R}^{\mathrm{T}}$ is shown in Table 2. The predominant fatty acids were anteiso- $\mathrm{C}_{15: 0}(57.4 \%)$, iso- $\mathrm{C}_{15: 0}(9.1 \%)$, iso- $\mathrm{C}_{16: 0}(9.1 \%)$ and $\mathrm{C}_{16: 0}(6.2 \%)$, which are also the predominant fatty acids of the type strains of closely related Cohnella species (Table 2); however, the proportions of anteiso- $\mathrm{C}_{15: 0}$ were lower $(30.4-36.1 \%)$ and of iso- $\mathrm{C}_{16: 0}$ were higher $(16.3-37.7 \%)$ in the other Cohnella type strains. The major polar lipids of strain $H Y-22 R^{T}$ were diphosphatidylglycerol, phosphatidylglycerol and phosphatidylethanolamine. Two unknown phospholipids, three unknown aminophospholipids and lysyl-phosphatidylglycerol were detected in minor amounts (Fig. 1). This profile is in agreement with the characteristics of Cohnella species (Kämpfer et al., 2006).

For phylogenetic analysis, genomic DNA was isolated from a fresh culture of strain $\mathrm{HY}-22 \mathrm{R}^{\mathrm{T}}$ following the methods of Sambrook et al. (1989). PCR amplification of the 16S rRNA gene was performed using an established method (Lane, 1991) and the PCR products were sequenced by Invitrogen Biotechnology. A preliminary phylogenetic analysis was performed using the EzTaxon database (Chun et al., 2007). Selected sequences were loaded into the software package MEGA version 4.0 (Tamura et al., 2007) and phylogenetic trees were constructed using the neighbour-joining (Saitou \& Nei, 1987) and maximum-

Table 2. Fatty acid patterns of strain $H Y-22 R^{\top}$ and the type strains of phylogenetically closely related Cohnella species

Strains: 1, C. luojiensis sp. nov. HY-22R ${ }^{\mathrm{T}} ; 2$, C. phaseoli KACC $13436^{\mathrm{T}}$; 3, C. hongkongensis KACC $11644^{\mathrm{T}} ; 4$, C. thermotolerans KACC $11643^{\mathrm{T}}$. Values are percentages of total fatty acids and were obtained in this study. - , Not detected or $<1 \%$.

\begin{tabular}{|c|c|c|c|c|}
\hline Fatty acid & 1 & 2 & 3 & 4 \\
\hline iso- $\mathrm{C}_{13: 0}$ & - & - & 1.4 & - \\
\hline anteiso- $\mathrm{C}_{13: 0}$ & 2.6 & 1.3 & 1.2 & - \\
\hline $\mathrm{C}_{14: 0}$ & 1.2 & 2.1 & 2.7 & 1.6 \\
\hline iso- $\mathrm{C}_{14: 0}$ & 1.4 & 4.2 & 4.3 & 3.0 \\
\hline anteiso- $\mathrm{C}_{15: 0}$ & 57.4 & 35.8 & 36.1 & 30.4 \\
\hline iso- $\mathrm{C}_{15: 0}$ & 9.1 & 11.2 & 11.8 & 15.4 \\
\hline $\mathrm{C}_{16: 0}$ & 6.2 & 13.0 & 12.9 & 5.2 \\
\hline iso- $\mathrm{C}_{16: 0}$ & 9.1 & 16.7 & 16.3 & 37.7 \\
\hline $\mathrm{C}_{16: 1} \omega 11 c$ & - & - & 1.5 & - \\
\hline $\mathrm{C}_{16: 1} \omega 7 c$ alcohol & - & 1.5 & 2.2 & 1.1 \\
\hline iso- $\mathrm{C}_{17: 0}$ & 3.7 & 2.8 & 1.7 & - \\
\hline anteiso- $\mathrm{C}_{17: 0}$ & 4.8 & 2.5 & 2.9 & 5.3 \\
\hline $\mathrm{C}_{17: 1} \omega 6 c$ & - & - & - & 1.0 \\
\hline $\mathrm{C}_{18: 0}$ & - & 3.6 & - & - \\
\hline Summed feature $8^{\star}$ & - & - & - & 1.7 \\
\hline
\end{tabular}

${ }^{\star}$ Summed features represent groups of two or three fatty acids that cannot be separated by the Microbial Identification System. Summed feature 8 consisted of $\mathrm{C}_{18: 1} \omega 7 c$ and/or $\mathrm{C}_{18: 1} \omega 6 c$. 


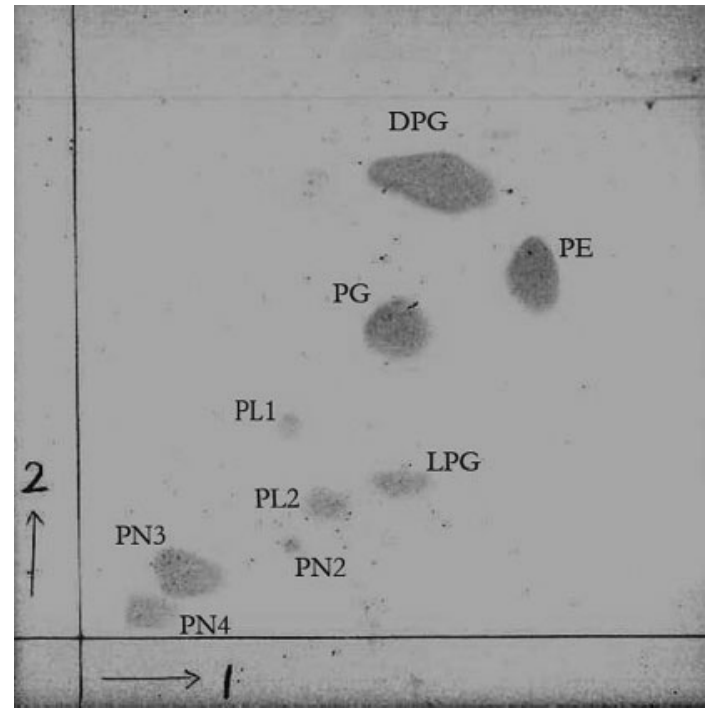

Fig. 1. Two-dimensional thin-layer chromatogram of polar lipids of strain HY-22R'. DPG, Diphosphatidylglycerol; LPG, lysylphosphatidylglycerol; $\mathrm{PE}$, phosphatidylethanolamine; $\mathrm{PG}$, phosphatidylglycerol; PL, unknown phospholipids; PN, unknown aminophosphoglycolipid.

parsimony (Fitch, 1971) methods. Evolutionary distances for the neighbour-joining algorithm were calculated with Kimura's two-parameter model (Kimura, 1980) and the topology of the neighbour-joining tree was evaluated by bootstrap analysis on the basis of 1000 replications (Felsenstein, 1985). Close-neighbour interchange (search level $=2$, random additions $=100$ ) was applied in the maximum-parsimony analysis.

The $16 \mathrm{~S}$ rRNA gene sequence of strain $\mathrm{HY}-22 \mathrm{R}^{\mathrm{T}}$ shared 93.7-96.3\% similarity (over $1458 \mathrm{nt}$ ) with all of the other Cohnella strains. The phylogenetic tree from the neighbour-joining analysis illustrates the phylogenetic relationships within the genus Cohnella (Fig. 2). Strain HY-22R ${ }^{\mathrm{T}}$ showed the highest 16S rRNA gene sequence similarity with C. phaseoli $\mathrm{GSPC1}^{\mathrm{T}}(96.3 \%)$. The topologies of phylogenetic trees generated using the maximum-parsimony algorithm were similar to those generated using neighbour-joining analysis (data not shown). According to Stackebrandt \& Goebel (1994) and Wayne et al. (1987), the levels obtained for 16S rRNA gene sequence similarity between strain HY- $22 \mathrm{R}^{\mathrm{T}}$ and the type strains of the other Cohnella species $(\leqslant 97 \%)$ supported the isolate's genomic distinction.

On the basis of the phenotypic variation and chemotaxonomic and phylogenetic analysis, strain $\mathrm{HY}-22 \mathrm{R}^{\mathrm{T}}$ should be classified in a novel species of the genus Cohnella, for which we propose the name Cohnella luojiensis sp. nov.

\section{Description of Cohnella luojiensis sp. nov.}

Cohnella luojiensis (lu.o.ji.en'sis. N.L. fem. adj. luojiensis pertaining to Luojia hill, the site of the campus of Wuhan University, where the type strain was characterized).

Cells are strictly aerobic, Gram-positive-staining, rodshaped $(0.4-0.6 \times 1.2-3.5 \mu \mathrm{m})$ and motile by means of peritrichous flagella. Oxidase- and catalase-positive. Oval subterminal spores are formed. Colonies on TSA are opaque, white, convex and about $1 \mathrm{~mm}$ in diameter after growth at $30{ }^{\circ} \mathrm{C}$ for $48 \mathrm{~h}$. Grows at $10-37{ }^{\circ} \mathrm{C}$ (optimum $30{ }^{\circ} \mathrm{C}$ ), at $\mathrm{pH} 6.0-8.0$ (optimum $\mathrm{pH} 7.0$ ) and with $0-1 \%$ $(\mathrm{w} / \mathrm{v}) \mathrm{NaCl}$. With API $20 \mathrm{NE}$ and API ZYM, positive for aesculin hydrolysis and esterase (C4), esterase lipase (C8), naphthol-AS-BI-phosphohydrolase, leucine arylamidase and $\alpha$ - and $\beta$-galactosidase activities, but negative for nitrate reduction, indole production, gelatin hydrolysis, glucose fermentation and alkaline phosphatase, acid phosphatase, lipase (C14), arginine dihydrolase, cystine arylamidase, valine arylamidase, urease, $\alpha$-fucosidase, $\alpha$ - and $\beta$-glucosidase, $\beta$-glucuronidase, $\alpha$-mannosidase, $N$-acetyl- $\beta$-glucosaminidase, trypsin and $\alpha$-chymotrypsin activities. With API 20NE and API ID 32GN, assimilates L-arabinose, L-fucose, D-glucose, inositol, maltose, D-mannitol, D-mannose, melibiose, D-ribose, salicin and sucrose, but not sodium acetate, trisodium citrate, $\mathrm{N}$-acetylgluco-

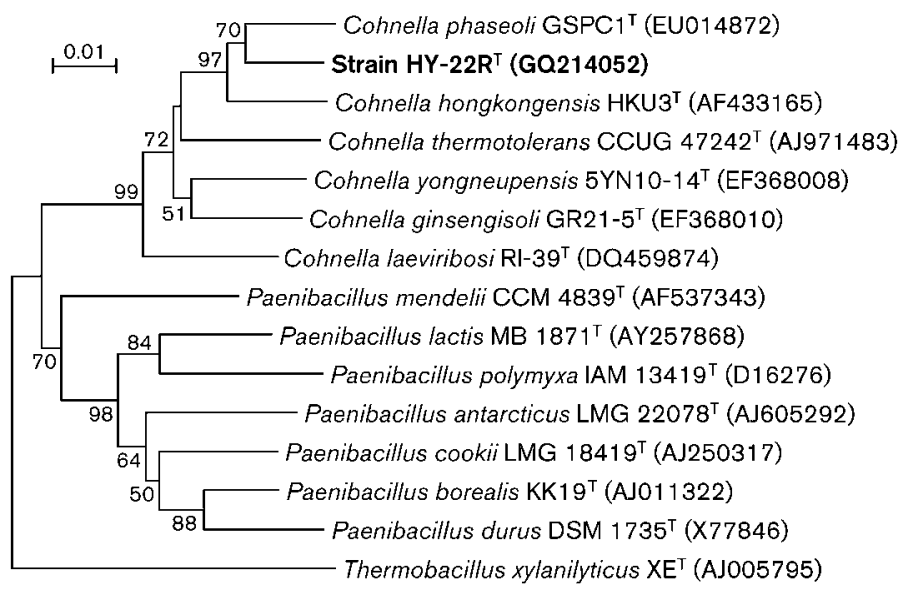

Fig. 2. Neighbour-joining tree based on $16 \mathrm{~S}$ rRNA gene sequence analysis (1458 nt), showing the phylogenetic relationships between strain $\mathrm{HY}-22 \mathrm{R}^{\top}$ and other related taxa. Bootstrap values $(>50 \%)$ based on 1000 replications are shown at branch nodes. Bar, 0.01 substitutions per nucleotide position. 
samine, glycogen, L-rhamnose, D-sorbitol, adipic acid, capric acid, itaconic acid, lactic acid, malic acid, phenylacetic acid, suberic acid, propionic acid, valeric acid, sodium malonate, L-alanine, L-serine, L-histidine, L-proline, potassium 2ketogluconate, potassium 5-ketogluconate, 3-hydroxybenzoic acid, 4-hydroxybenzoic acid or 3-hydroxybutyric acid. The major respiratory quinone is MK-7 and the predominant fatty acids are anteiso- $\mathrm{C}_{15: 0}$, iso- $\mathrm{C}_{15: 0}$, iso- $\mathrm{C}_{16: 0}$ and $\mathrm{C}_{16: 0}$. Major polar lipids are diphosphatidylglycerol, phosphatidylglycerol and phosphatidylethanolamine. In addition, lysyl-phosphatidylglycerol, two unknown phospholipids and three unknown aminophospholipids are also detected. The DNA $\mathrm{G}+\mathrm{C}$ content of the type strain is $49.6 \mathrm{~mol} \%$.

The type strain, HY-22R ${ }^{\mathrm{T}}$ (=CCTCC AB $208254^{\mathrm{T}}=$ NRRL B-59213 ${ }^{\mathrm{T}}$ ), was isolated from a soil sample from Xinjiang, China.

\section{Acknowledgements}

This work was supported by the R \& D Infrastructure and Facility Development Program from the Ministry of Science and Technology of the People's Republic of China (grant no. 2005DKA21208).

\section{References}

Cho, E. A., Lee, J. S., Lee, K. C., Jung, H. C., Pan, J. G. \& Pyun, Y. R. (2007). Cohnella laeviribosi sp. nov., isolated from a volcanic pond. Int J Syst Evol Microbiol 57, 2902-2907.

Chun, J., Lee, J.-H., Jung, Y., Kim, M., Kim, S., Kim, B. K. \& Lim, Y. W. (2007). EzTaxon: a web-based tool for the identification of prokaryotes based on $16 \mathrm{~S}$ ribosomal RNA gene sequences. Int J Syst Evol Microbiol 57, 2259-2261.

Collins, M. D., Pirouz, T., Goodfellow, M. \& Minnikin, D. E. (1977). Distribution of menaquinones in actinomycetes and corynebacteria. J Gen Microbiol 100, 221-230.

Doetsch, R. N. (1981). Determinative methods of light microscopy. In Manual of Methods for General Bacteriology, pp. 21-33. Edited by P. Gerhardt, R. G. E. Murray, R. N. Costilow, E. W. Nester, W. A. Wood, N. R. Krieg \& G. H. Phillips. Washington, DC: American Society for Microbiology.

Felsenstein, J. (1985). Confidence limits on phylogenies: an approach using the bootstrap. Evolution 39, 783-791.

Fitch, W. M. (1971). Toward defining the course of evolution: minimum change for a specific tree topology. Syst Zool 20, 406-416.

Garcia-Fraile, P., Velázquez, E., Mateos, P. F., Martínez-Molina, E. \& Rivas, R. (2008). Cohnella phaseoli sp. nov., isolated from root nodules of Phaseolus coccineus in Spain, and emended description of the genus Cohnella. Int J Syst Evol Microbiol 58, 1855-1859.
Kämpfer, P., Rosselló-Mora, R., Falsen, E., Busse, H.-J. \& Tindall, B. J. (2006). Cohnella thermotolerans gen. nov., sp. nov., and classification of 'Paenibacillus hongkongensis' as Cohnella hongkongensis sp. nov. Int J Syst Evol Microbiol 56, 781-786.

Kim, S. J., Weon, H. Y., Kim, Y. S., Anandham, R., Jeon, Y. A., Hong, S. B. \& Kwon, S. W. (2010). Cohnella yongneupensis sp. nov. and Cohnella ginsengisoli sp. nov., isolated from two different soils. Int $J$ Syst Evol Microbiol 60, 526-530.

Kimura, M. (1980). A simple method for estimating evolutionary rates of base substitutions through comparative studies of nucleotide sequences. J Mol Evol 16, 111-120.

Lane, D. J. (1991). 16S/23S rRNA sequencing. In Nucleic Acid Techniques in Bacterial Systematics, pp. 115-147. Edited by E. Stackebrandt \& M. Goodfellow. Chichester: Wiley.

Mesbah, M., Premachandran, U. \& Whitman, W. B. (1989). Precise measurement of the $\mathrm{G}+\mathrm{C}$ content of deoxyribonucleic acid by highperformance liquid chromatography. Int J Syst Bacteriol 39, 159167.

Moore, D. D. \& Dowhan, D. (1995). Preparation and analysis of DNA. In Current Protocols in Molecular Biology, pp. 2-11. Edited by F. W. Ausubel, R. Brent, R. E. Kingston, D. D. Moore, J. G. Seidman, J. A. Smith \& K. Struhl. New York: Wiley.

Saitou, N. \& Nei, M. (1987). The neighbor-joining method: a new method for reconstructing phylogenetic trees. Mol Biol Evol 4, 406425.

Sambrook, J., Fritsch, E. F. \& Maniatis, T. (1989). Molecular Cloning: a Laboratory Manual, 2nd edn. Cold Spring Harbor, NY: Cold Spring Harbor Laboratory.

Sasser, M. (1990). Identification of bacteria by gas chromatography of cellular fatty acids, MIDI Technical Note 101. Newark, DE: MIDI Inc.

Smibert, R. M. \& Krieg, N. R. (1994). Phenotypic characterization. In Methods for General and Molecular Bacteriology, pp. 607-654. Edited by P. Gerhardt, R. G. E. Murray, W. A. Wood \& N. R. Krieg. Washington, DC: American Society for Microbiology.

Stackebrandt, E. \& Goebel, B. M. (1994). Taxonomic note: a place for DNA-DNA reassociation and $16 \mathrm{~S}$ rRNA sequence analysis in the present species definition in bacteriology. Int J Syst Bacteriol 44, 846849.

Tamura, K., Dudley, J., Nei, M. \& Kumar, S. (2007). MEGA4: molecular evolutionary genetics analysis (MEGA) software version 4.0. Mol Biol Evol 24, 1596-1599.

Tindall, B. J. (1990). Lipid composition of Halobacterium lacusprofundi. FEMS Microbiol Lett 66, 199-202.

Wayne, L. G., Brenner, D. J., Colwell, R. R., Grimont, P. A. D., Kandler, O., Krichevsky, M. I., Moore, L. H., Moore, W. E. C., Murray, R. G. E. \& other authors (1987). International Committee on Systematic Bacteriology. Report of the ad hoc committee on reconciliation of approaches to bacterial systematics. Int J Syst Bacteriol 37, 463-464.

Xie, C. H. \& Yokota, A. (2003). Phylogenetic analysis of Lampropedia hyalina based on the 16S rRNA gene sequence. J Gen Appl Microbiol 49, 345-349. 